\title{
O PATRIMÔNIO DOCUMENTAL BAIANO: DESCRIÇÃO MATERIAL DE DOCUMENTOS DO SÉCULO 19
}

Bahia's documental heritage: Material description of documents from the 19th century

\author{
Alícia Duhá Lose/UFBA \\ alicia.lose@ufba.br \\ Vanilda Salignac Mazzoni/Memória e Arte \\ vanildasalignac@gmail.com
}




\section{Resumo}

Este artigo trata da identificação de manuscritos antigos com status de documentos históricos a partir do olhar da prática cotidiana do Ateliê de Conservação e Restauração Memória e Arte, localizado na cidade do Salvador, Bahia, Brasil. A intenção é mostrar a importância da inventariação a partir da descrição do suporte partindo de elementos presentes nos documentos e que não nos deixam dúvidas de sua importância e da necessidade de conservá-los e protegê-los enquanto patrimônio documental. Utilizou-se como referência documentos manuscritos tratados pelo referido Ateliê e que foram produzidos no século XIX, sem nenhuma intenção de serem classificados com valoração histórica, mas que, com o passar dos séculos, se tornaram documentos relevantes, o que significa que a sua perda levará a uma lacuna na nossa história. São documentos, portanto, não passíveis de descarte, prática recorrente a determinados documentos arquivísticos.

Palavras-chave: Manuscrito. Bahia. Inventário. Documento histórico.

\section{Abstract}

This article deals of the identification of old manuscripts with historical document status from the perspective of the daily practice of the Atelier of Conservation and Restoration Memória e Arte, located in the city of Salvador, Bahia, Brazil. The intention is to show the importance of the inventory based on the description of the support, starting from elements present in the documents and which leave us in no doubt of their importance and the need to preserve and protect them as documentary heritage. It was used as a reference manuscript documents treated by the referred Ateliê and that were produced in the 19th centuries, with no intention of being classified with historical value, but that over the centuries have become a relevant document, which means that their loss will lead us to a gap in our history, therefore, without the power to discard such as is done with certain archival documents.

Keywords: Manuscript. Bahia. Inventory. Historical document. 


\section{INTRODUÇÃO}

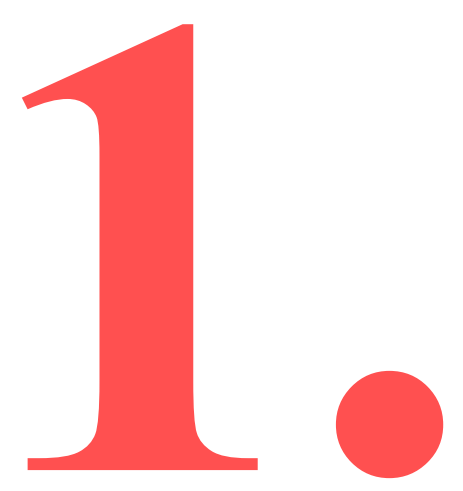

Em 1549, a cidade de Salvador, capital da chamada, à época, Província da Bahia, foi escolhida para ser a primeira sede oficial do Governo Geral português em terras brasileiras. Quase cinco séculos depois, muita documentação que foi produzida a partir das atividades burocráticas do governo, das ordens religiosas, ou de uma série de histórias nascidas na oralidade, muitas vezes por mãos que acreditavam traduzir fatos que (supostamente) os olhos vivenciaram, ainda existe. O objetivo deste breve artigo é descrever as características da produção desses documentos escritos à mão, portanto, manuscritos, do século XIX na Bahia e mostrar como eles se tornaram - por serem, nos casos aqui apontados, originais - fontes históricas primárias para as pesquisas sobre os períodos Colonial, Imperial e Republicano no Brasil. Sua importância mostra-se maior se lembrarmos que Salvador se manteve como capital do país até 1763 e, mesmo com a transferência da sede do governo para o Rio de Janeiro, a Província da Bahia ainda conservou um respeitável status político, e os registros produzidos na época continuam sendo tomados como referências para variados estudos.

Segundo Priore (2016), dependendo da finalidade, o estatuto de um documento varia: uns são emblemáticos para momentos específicos da história; outros abrem portas de um mundo desconhecido; outros são de ordem patrimonial e se relacionam com a construção da nossa memória. Todos eles são importantes porque há sempre um viés de interesse de um 
pesquisador e que irá se surpreender diante dos fatos apresentados nas linhas e entrelinhas dos textos.

Além do fato de ser extraordinário do ponto de vista histórico, também é muito sedutor estar diante de um manuscrito antigo. Como nos aponta Hamel (2017, p. 8-9), “[...] nenhuma cópia se iguala a um original. [...] Ninguém pode propriamente conhecer um manuscrito ou escrever sobre ele sem tê-lo visto e segurado nas mãos". A emoção é outra: o cheiro, a cor, o traçado, a tinta, o envelhecimento, as marcas de desgaste, a percepção do tempo na construção da escrita histórica, as mudanças de mãos sobre o papel. Tudo isso atrai e encanta um pesquisador.

Um documento manuscrito adquire status de patrimônio documental histórico a partir de suas características vinculadas ao valor estético, cultural, material, social, identitário, de memória e de conteúdo. Isto significa que o documento não nasce com esse status, ele se torna histórico. É fonte permanente de informação, mas também é objeto, artefato, não só conteúdo, e por essas características não se aplica a esse tipo de documento o critério de elegibilidade para descarte. E se não pode ser descartado, tem que ser preservado.

E é essa sensação regozijante que temos diariamente em nosso Ateliê de conservação e restauração de documentos antigos, que queremos descrever para o leitor neste texto. Muito além de ser um ateliê de conservação e restauração de papel, o Memória e Arte é uma instituição de salvaguarda do patrimônio documental baiano, localizada em Salvador, que cuida de inúmeros documentos manuscritos de importância histórica que enriqueceram a relação luso-brasileira ao longo dos séculos. Assim, mostraremos, a partir de nossa experiência cotidiana, como identificamos e analisamos cada documento a fim de conferir sua importância histórica. Normalmente, quando o proprietário do acervo documental nos procura, ele quase nunca sabe do que trata sua coleção/fundo, pois não "consegue" 
entender o que está escrito ali, apenas reconhece que é antigo pela aparência física do suporte. Cabe a nós conhecermos o documento antes de restaurá-lo. Aqui não comentaremos o processo de restauro e sim os elementos que levamos em consideração para lhe conferir o estatuto de documento histórico.

Para iniciarmos os trabalhos com qualquer documentação que chega até nós, enquanto primeiro ato, fazemos o inventário, que nada mais é do que relacionar, listar discriminadamente, registrar características físicas específicas do manuscrito e descrever seu conteúdo. Para uma eficiente gestão do espaço de guarda, o inventário é importante porque a partir do registro documental completo é possível se tornar conhecedor de um acervo. Essa primeira ação pode ser feita pelo próprio gestor ou proprietário, basta que ele tenha competências específicas que podem ser adquiridas com estudos acerca da materialidade documental.

Como dito, no inventário caracterizamos o documento, individualizando-o (no sentido de reconhecê-lo como singular em seu conteúdo e representatividade histórica). Os objetivos da identificação e análise de manuscritos são variados: (1) avaliar a condição do suporte para julgar se ele pode ainda ser manipulado, por exemplo; (2) saber se ele pode ser disponibilizado para consulta ou já deve ser retirado de acesso resguardandoo para protegê-lo; (3) auxiliar no processo de restauração / conservação - se não apresenta condições de manipulação, um conservador-restaurador deve ser consultado para indicar o melhor tratamento -; (4) conhecer o acervo - é preciso saber quais assuntos se pode disponibilizar ao leitor/pesquisador, qual o tema recorrente de documentação; (5) não se concebe que um gestor desconheça seu acervo; (6) controlar o acervo - se conhecemos, possuímos condições de controlar o acesso a partir de condição física e da necessidade de cada pesquisador; (7) fazer a descrição informativa do suporte precisamos saber de sua materialidade -; (8) proteger o patrimônio histórico - se identificamos como patrimônio histórico, podemos assegurar apoio financeiro e executar ações de salvaguarda; (9) reconhecê-lo em caso de 
extravio e posterior recuperação por parte das autoridades: manuscrito é documento único, portanto, sua originalidade é inquestionável, mas existem cópias perfeitas. E a meta principal deve ser reconhecer o acervo pela importância patrimonial/cultural que ele representa.

Como segundo ato, fazemos a leitura do documento para reconhecer e compreender o seu conteúdo e, consequentemente, seu valor histórico a partir do assunto. Para isso, contamos com uma equipe de paleógrafos que nos auxiliam na transcrição de cada documento que chega ao Ateliê. Esse conjunto de ações nos ajuda no reconhecimento do documento enquanto patrimônio documental histórico. 


\section{A IMPORTÂNCIA DA \\ MATERIALIDADE DO \\ SUPORTE: IDENTIFICAÇÃO \\ E ANÁLISE DO DOCUMENTO HISTÓRICO INTRODUÇÃO}

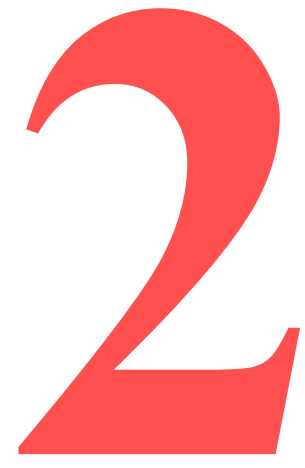

Belloto (2007) afirma que a organização de documento em fundo torna o arquivo permanente (que é o caso dos documentos históricos) organizado e lógico, porém a descrição é a única maneira de possibilitar que os dados contidos nele cheguem ao pesquisador. Ao valor primário do documento (o uso pelo produtor) se junta o valor secundário (o uso que se faz da informação no suporte), que deve ser mais amplo: nesse momento, “[...] a descrição destina-se àquela cuja tarefa é explorar o que restou, após ter-se cumprido a finalidade administrativa ou jurídica do ato" (BELLOTO, 2007, p. 178).

Embora a descrição apresentada por Belloto difira de nossa identificação em relação aos elementos contidos no documento, o que estamos levando em consideração é a importância de descrevê-lo para que o suporte seja de fato um instrumento de pesquisa, pois ao inventariá-lo estamos dissecando sua materialidade (descrição física) e identificando o assunto, o que muito facilita o trabalho do pesquisador ou do simples leitor curioso. Mas, antes de discutirmos acerca da identificação e descrição do documento, precisamos evidenciar o conceito de documento histórico.

A partir de que momento esse manuscrito passa a ser um "documento histórico"? Para nós, o documento histórico é a fonte material que relata 
algum feito, ato, ação, em um determinado período e que se torna de interesse público com o passar do tempo por interferir em um conhecimento maior de uma época, influencia o presente quando nos revela um fato desconhecido até então, que desvenda ou não a formulação de um problema, contanto que ofereça a leitura e pesquisa no assunto. Quem transforma um simples manuscrito em documento histórico e fonte primária é o olhar do pesquisador. Funari (2005, p. 84-85) acrescenta e amplia o sentido:

Pressupondo que a História se escreve com documentos, a primeira providência dos historiadores, a partir das décadas iniciais do século XIX, foi a publicação de documentos antigos, transmitidos pela tradição textual dos copistas, em edições com aparatos críticos, ou seja, com notas sobre as diferenças entre os manuscritos. Iniciou-se, pois, a publicação de coleções de obras latinas e gregas, primeiro, e depois de uma infinidade de textos em línguas antigas, medievais e modernas. Ao mesmo tempo, começou a surgir a preocupação com a preservação de documentos de arquivos, com a criação de instituições arquivísticas públicas e com critérios próprios. Uma conseqüência natural dessa preocupação com a documentação fez surgir grandes iniciativas arqueológicas de coleta e publicação de artefatos, edifícios e outros aspectos da cultura material, que deve ser entendida como tudo que é feito ou utilizado pelo homem.

Após sua classificação e reconhecimento de seu valor histórico, passamos para a descrição desse documento, mas não sem antes nos perguntarmos quais elementos devemos levar em consideração para inventário no momento de sua identificação. Necessitamos, a priori, do aporte de três ciências: a Codicologia, a Diplomática e a Paleografia.

A Codicologia é uma ciência que estuda a técnica dos livros manuscritos, ou seja, os códices. Segundo Cambraia (2005, p. 26), "Para o crítico textual, a codicologia é de grande relevância, pois fornece informações que permitem 
compreender algumas das razões pelas quais os textos se modificam no processo de sua transmissão".

A Diplomática consiste no estudo da matéria escriptória, dos instrumentos gráficos, das tintas, dos selos, das bulas, dos timbres, da letra, da linguagem, das fórmulas, em uma crítica formal dos documentos. Os procedimentos diplomáticos auxiliam a situar os documentos no tempo e no espaço.

A Paleografia é a ciência que estuda a escrita antiga sob suporte macio (pergaminho ou papel). Sem o auxílio dela seria impossível a decifração do conteúdo dos textos devido à complexidade da produção escrita que atravessa séculos e vai sendo influenciada por tipos específicos de letras e características específicas de mãos. A abordagem interdisciplinar com essas três ciências nos ajuda a compreender tanto a necessidade da salvaguarda desses documentos quanto suas potencialidades enquanto fonte primária de pesquisa e estudos históricos.

Portanto, embora, a rigor, não possamos usar o termo Codicologia para descrever documentos manuscritos posteriores ao século $\mathrm{XV}$, bem como não possamos usar o termo Diplomática para tratar de documentos que não tenham sido vazados dentro das fórmulas diplomáticas convenientes, é comum tomarmos por empréstimo itens dessas duas ciências analíticodescritivas na análise e na descrição de documentos manuscritos mais modernos, pois nos interessa saber particularidades sobre a produção escrita de cada um deles. Portanto, importa compreender e descrever o tipo de tinta utilizada na escrita; a tipologia documental (se é carta, documento administrativo, ata, etc.); quem são o emissor e o receptor do texto; qual a sua datação; o seu local de origem; procedência do fundo/coleção; quais suas dimensões; o número de fólios; o tamanho da mancha escrita; o número de linhas; a existem ou não de abreviaturas; em qual idioma foi produzido; se possui anotação posterior; qual tipo de papel ele foi produzido; se existem 
marcas de propriedade ou marca de proveniência, se o texto é colunado; se há selos, sinetes ou estampilhas; de que assunto trata; qual é o seu estado de conservação, entre outros.

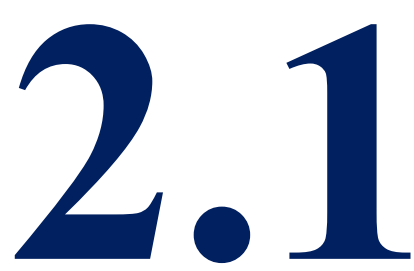

\section{Descrição física de um documento manuscrito}

Mostraremos, a partir de exemplos extraídos de um acervo por nós trabalhado, os elementos materiais básicos, mais visíveis em um primeiro contato, que podem conferir o imediato valor histórico aos documentos: presença de estampilhas, lacres, selos, assinaturas em público e raso, datação, características de produção do texto em tinta metaloácida, orgânica ou carbonada, validações e chancelas de escrivães, estado de língua em que foi cunhado o documento apresentando grafias, vocabulário e pronomes de tratamento característicos de um dado período, papel de cor amarelada, produzido em trapos com vergaturas, pontusais e marcas d'água, ou em celulose. A existência de todos esses elementos nos comprova que estamos diante de um documento histórico e que merece ser analisado, descrito e conservado.

As imagens a seguir são de documentos pertencentes a um fundo documental arquivístico-histórico do Recolhimento dos Humildes, fundado em 1798 e legalmente autorizado em 1817, como Centro de Educação Feminina e Recolhimento para meninas, pelo Padre Ignácio Teixeira dos Santos e Araújo, na cidade de Santo Amaro da Purificação, na Província da Bahia, Vila de Santo Amaro, Brasil. No ano de 1927, a instituição deixou de ser um Recolhimento, tornou-se um convento feminino e foi elevado à categoria de Congregação, pela qual uma escola é mantida até os dias atuais. 
Esses documentos aqui apresentados são administrativos e originalmente não "nasceram" com a condição de manuscritos históricos patrimoniais, adquiriram tal status por serem a única fonte informativa que conta a trajetória da instituição, incluindo os seus propósitos, os nomes dos fundadores e a forte ligação entre a Igreja Católica e o poder político de Portugal há época de sua fundação, visando à autorização de uma importante e necessária instituição religiosa para abrigar mulheres em terras da Colônia.

$\mathrm{Na}$ imagem a seguir (Figura 1), é possível perceber o uso de selos imperiais de impostos, no valor de 200 réis cada, e assinaturas em público e raso, os quais nos fornecem a informação de que estamos diante de um documento de valor público. Lendo o texto, vemos tratar-se de um translado com fé pública de documento de compra e venda, escrito por um único scriptor, em letra humanística cursiva do séc. XIX, e traçado bastante caligráfico. A leitura paleográfica do texto nos permite identificar quando o documento foi escrito - 07/04/1873; onde foi escrito - Bahia; por quem foi produzido e validado = Basílio José do Sacramento Baraúna; por que foi escrito - é um documento de compra e venda de uma casa; para quem foi escrito - Francisca de Mello Teixeira, a vendedora, e Maria Francisca Telles, a compradora. E os elementos de validação, as fórmulas diplomáticas utilizadas, as características linguísticas presentes no texto, o tipo de papel e a tinta utilizadas nos confirmam tratar-se de um documento autêntico, correspondente à datação tópica e cronológica apresentadas.

Figura 1: Documento de compra e venda 


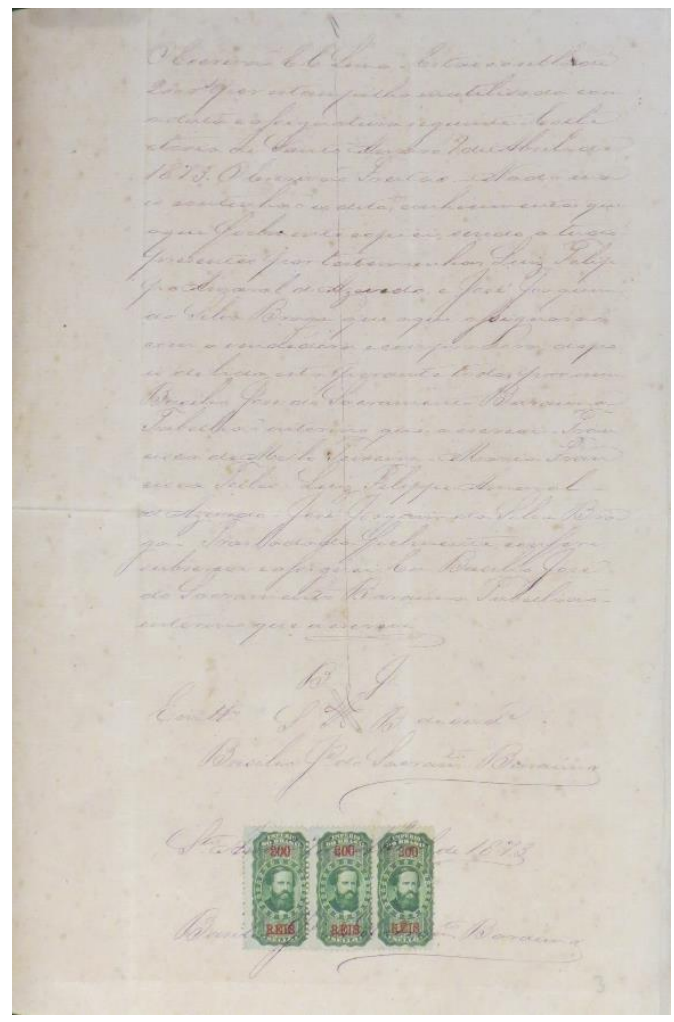

Fonte: Recolhimento dos Humildes/Memória e Arte

O segundo documento é de 18/09/1817. São embargos feitos pelo Padre Ignacio dos Santos contra os parentes de Francisco Soares de Albergaria que protestaram juridicamente pelo fato de esse ter doado, em testamento, bens ao Recolhimento dos Humildes. O documento é produzido por Malachias dos Santos, tabelião da Provedoria, na ausência do escrivão da mesma, Joaquim Antonio de Athayde e Seixas, na Vila de Santo Amaro. Embora o documento não apresente assinaturas ou outras formas de validação legal, ele traz as fórmulas diplomáticas previsíveis, características linguísticas e abreviaturas peculiares ao séc. XIX e recorrentes nessa tipologia documental; foi produzido sobre papel avergoado, com vergaturas e pontusais, e escrito com bico de pena em tinta metaloácida por um único scriptor em letra humanística cursiva do séc. XIX. Portanto, as características materiais e estruturais do documento condizem com a data tópica e cronológica nele apresentadas e nos levam a crer tratar-se de um original. 
Figura 2: Documento de embargo

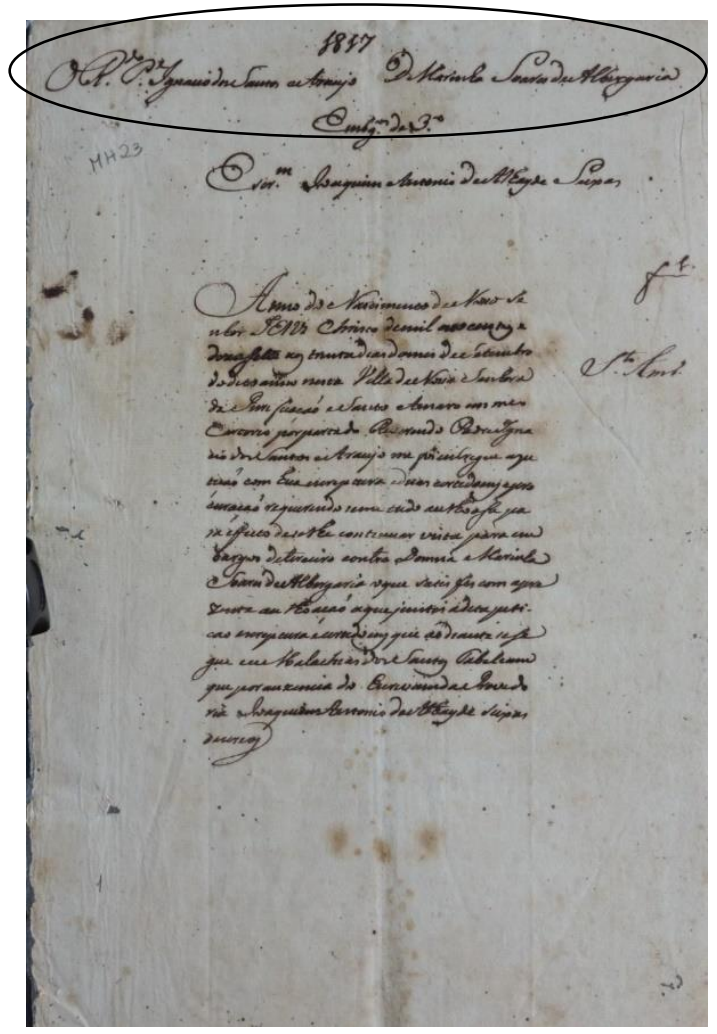

Fonte: Recolhimento dos Humildes/Memória e Arte

Já o terceiro documento traz logo na sua fórmula inicial as abreviaturas referentes aos pronomes de tratamento para identificar o destinatário: Illustrissimo Reverendissimo Senhor Padre Mestre Frei Bento de Maria Santissima. Trata-se de uma carta de apresentação e recomendação, remetida pelo Arcebispo da Bahia Dom Romualdo Seixas e por ele assinada. O destinatário é o Padre Mestre Frei Bento de Maria Santíssima. A carta é datada de 01/12/1850; apresenta carimbo seco do lado esquerdo superior (já bem clarinho); tem como assunto a comunicação da visita do sacerdote Padre Gabet ao Recolhimento dos Humildes, recomendando que este seja bem recebido. O documento foi produzido com bico de pena, com tinta metaloácida marrom, por um único scriptor em letra humanística cursiva do séc. XIX. Apresenta assinatura e traz as fórmulas diplomáticas previsíveis, características linguísticas e abreviaturas peculiares ao séc. XIX e recorrentes nessa tipologia documental; foi produzido sobre papel avergoado, com vergaturas e pontusais. Portanto, as características materiais e estruturais do documento condizem com a data tópica e cronológica nele apresentadas. Por conhecermos outros tantos documentos autógrafos do mesmo scriptor, podemos afirmar tratar-se de um original. 
Figura 1: Carta de Dom Romualdo, Arcebispo do Brasil

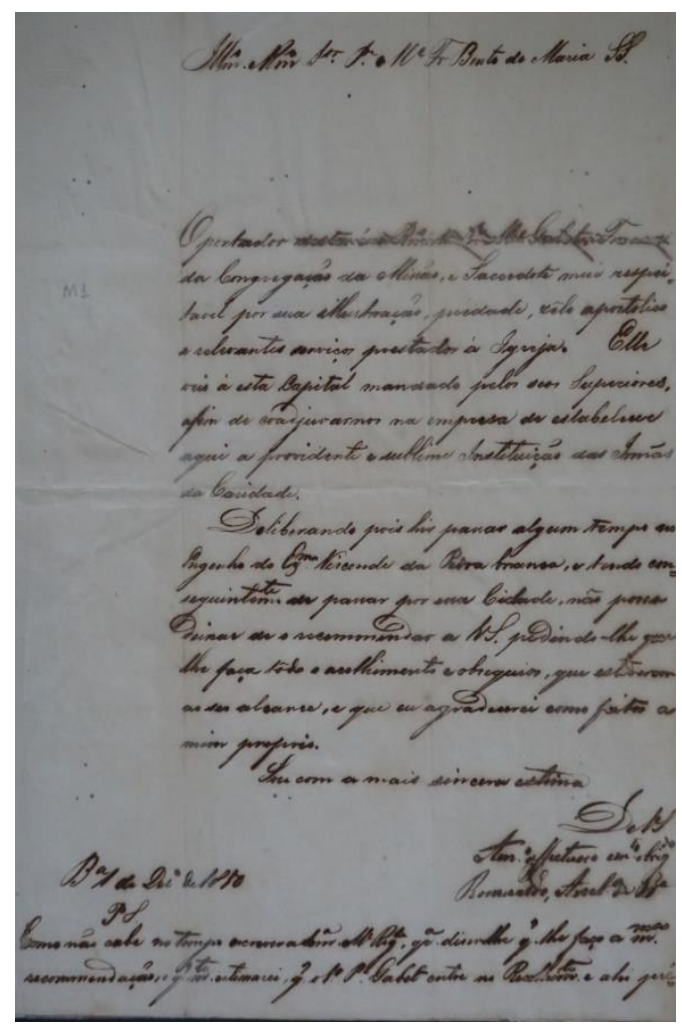

Fonte: Recolhimento dos Humildes/Memória e Arte

No quarto exemplo, vemos outros elementos importantes para identificação e caracterização do documento em questão. Embora não tenha sido posto o sinete de autoria conforme seria esperado, vemos pingos de cera utilizados para lacre. O texto foi produzido com bico de pena e tinta metaloácida por um único scriptor. Embora o suporte se encontre bastante danificado, é possível perceber tratar-se do envelope no qual se continha o testamento de Padre Ignacio Araujo (fundador do Recolhimento dos Humildes), confirmado e assinado pelo Padre Domingos Duarte Nunes. O documento é original e datado de 16/06/1818.

No quinto documento, vemos um selo de chapa (recortado, colado com goma e prensado a seco). O texto é escrito em bico de pena com tinta metaloácida produzido em letra humanística cursiva do séc. XIX, bastante caligráfica, por um único scriptor. O documento é datado de 23/09/1829 e é um Termo de Visita ao Recolhimento dos Humildes, feita pelo Arcebispo da Bahia, Dom Romualdo Antonio de Seixas, Primaz do Brazil, do Consêlho de Sua Majestade o 
Imperador, Grande Dignitario da Ordem da Rosa Gram Cruz de Christo, que saiu da Província da Bahia para a Vila de Santo Amaro da Purificação, no Recôncavo Baiano. Além do suporte utilizado, da tinta, do instrumento da escrita e dos elementos de validação, o estado de conservação do documento também marca a temporalidade e todos devem ser considerados e mencionados nas análises e descrições para atribuição de valor histórico aos documentos.

Figura 2: Testamento de Padre Ignácio de Araújo

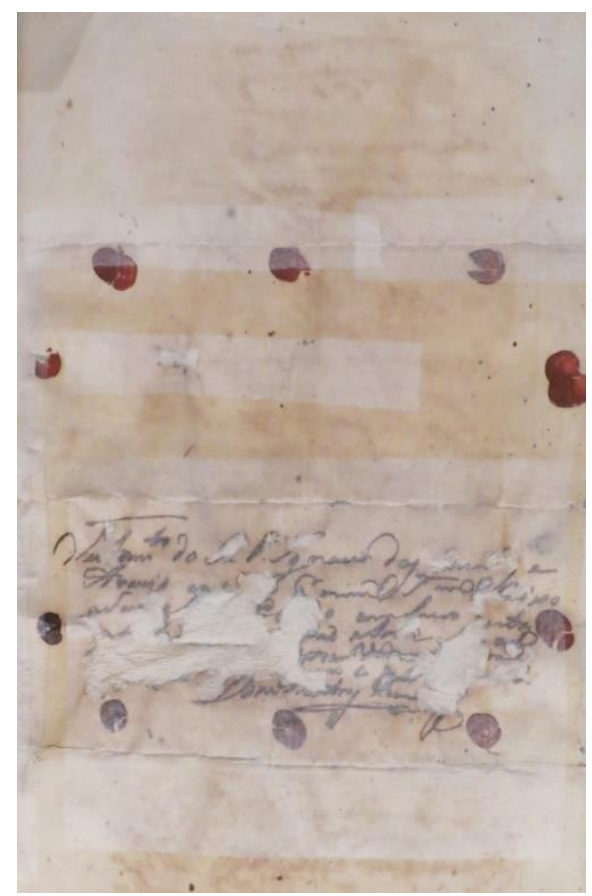

Fonte: Recolhimento dos Humildes/Memória e Arte 
Figura 3: Termo de Visita

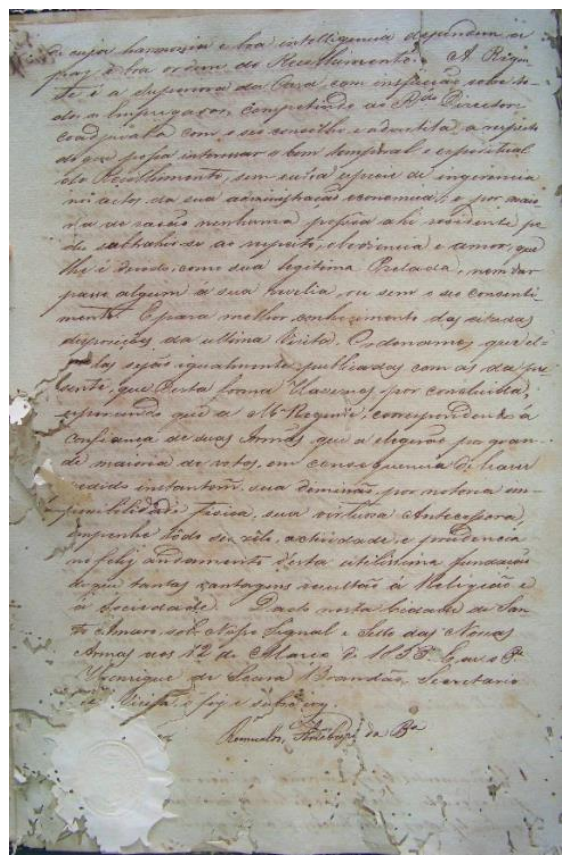

Fonte: Recolhimento dos Humildes/Memória e Arte

O sexto e sétimo documentos trazem como elementos de destaque uma marca d'água - uma filigrana que dá origem a uma marca na folha de papel no momento da sua produção, que corresponde a uma figura formada por finos fios metálicos, bordados ou aplicados sobre a superfície da teia da forma manual ou do rolo filigranador -; e ainda apresenta as vergaturas - as teias metálicas onde se faziam as tramas mais finas e que também geram os pontusais: os fios mais grossos para dar resistência às tramas no molde (MARTINS, 2002). Tais elementos também são importantes para análise e descrição dos documentos, pois ajudam a validálos como originais e situá-los cronologicamente.

Essas duas características são importantíssimas porque informam sobre a trajetória da história da introdução do papel em Portugal e no Brasil. Os documentos anteriores a 1808, data da chegada da Família Real ao Brasil, trazem marcas d'águas muito variadas, o que significa que o Brasil recebia remessas de papel provenientes de lugares distintos, conforme ocorria também em Portugal. A primeira fábrica de papel no Brasil surge com a vinda da Família Real portuguesa, foi construída no Andaraí Pequeno (no Rio de Janeiro), fundada 
entre 1808 e 1810, por Henrique Nunes Cardoso e Joaquim José da Silva. Em 1837 surge a indústria de André Gaillar; e em 1841, a de Zeferino Ferrez. Esses conhecimentos nos auxiliam principalmente quando o documento não é datado, algo muito comum até o século 19. Pela identificação e análise da marca d'água podemos afirmar se o documento é original ou não na relação entre o suporte e o tempo da escrita bem como seu assunto.

Figura 4: Carta de Frei Bento Maria

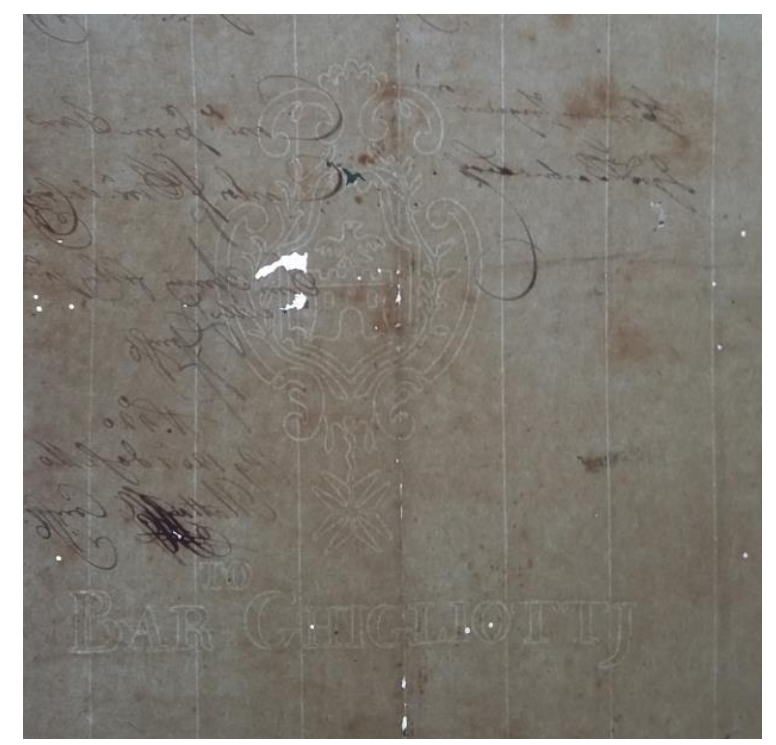

Fonte: Recolhimento dos Humildes/Memória e Arte

Figura 5: Termo de Visita

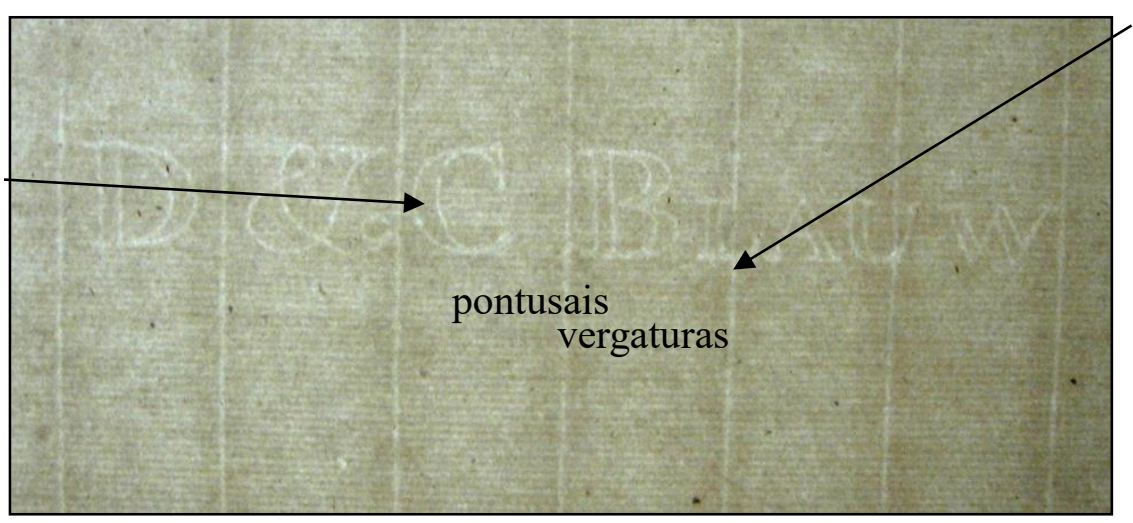

Fonte: Recolhimento dos Humildes/Memória e Arte

Uma característica somada à outra aumenta as informações que devem ser levadas em consideração para avaliação do reconhecimento de um manuscrito como documento histórico, e, portanto, patrimônio cultural. 
O documento manuscrito não é um tipo de fonte de pesquisa que possa ficar à disposição do leitor, à mercê de sua necessidade. Muitas vezes é necessário haver protocolos de proteção com o objetivo de aumentar sua durabilidade, pois o papel, por mais que se saiba que dure séculos, ainda é um suporte muito frágil e o manuseio constante e, muitas vezes, inadequado, o desgasta e pode levar à sua perda. Mas, para determinadas áreas do conhecimento, como a Codicologia, a Diplomática, a Paleografia, a Filologia e a História, quanto mais informações sobre o suporte, a estrutura, a scripta, o estado de língua entre outros, melhor para compreensão do conteúdo e do seu contexto.

O oitavo e último documento manuscrito por nós apresentado, traz sinais de oxidação com pequenas perdas de suporte; texto colunado, provavelmente para economizar papel, bem como o uso das abreviaturas anteriormente citadas em momentos em que a escassez e o preço do papel eram exorbitantes. Mostramos aqui um dos fólios de um documento composto por 8 fólios, todo escrito em bico de pena, por um único scriptor, em letra humanística cursiva do séc. XIX, em tinta metaloácida de coloração marrom, já bastante oxidada, apresentando perda de suporte onde houve a corrosão da tinta. Trata-se de um inventário de bens do Recolhimento dos Humildes que Padre Ignacio Araujo, o fundador da instituição, entrega à Madre Regente Anna Roberta da Cruz. O documento é autógrafo, datado de 09/12/1817 e assinado pelo próprio pároco na Vila de Santo Amaro, Bahia.

Figura 6: Inventário de bens do Recolhimento dos Humildes 


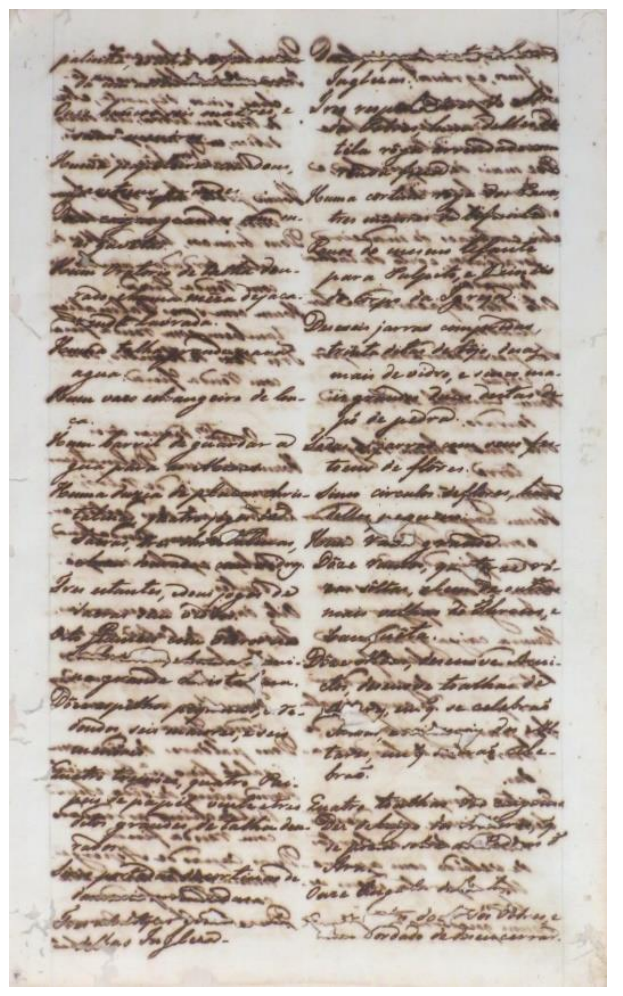

Fonte: Recolhimento dos Humildes/Memória e Arte 


\section{ENCERRANDO}

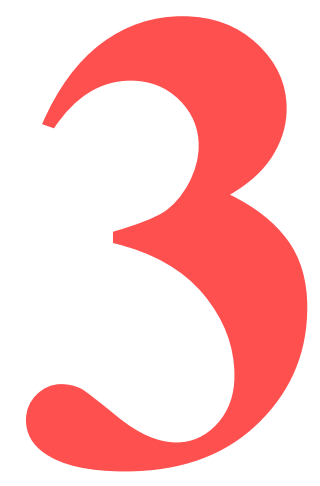

Neste breve artigo, intencionamos apontar elementos relevantes para auxiliar na identificação e reconhecimento de documentos manuscritos históricos e que, por assim serem considerados, não devem ser suscetíveis ao descarte e nem preteridos às fontes secundárias, terciárias, ou quais outras, pois neles pode estar algum trecho da história que, ao ser perdido, parte o "fio de Ariadne".

São muitas características e muitos elementos a serem levados em consideração nessa identificação, mas nosso conselho, advindo da prática e da experiência no lidar com acervos históricos documentais, é nunca se deixar levar pela aparência do suporte, pois o estado de conservação - papel degradado, manchas de umidade, presença de fungos, sinais de ataques de insetos papirófagos etc. -, não deve ser critério para desconsideração e descarte de documentos de valor patrimonial. É necessário que o pesquisador tenha uma postura investigativa, analítica e perseverante para não se deixar levar pelas primeiras impressões e cair na falácia de considerar equivocadamente cópias como originais, escrita autoral como escrita delegada, mudanças de tinta ou de instrumento de escrita como mudanças de scriptor e, o que é pior, para nunca considerar "documentos históricos" como “documentos velhos". Afinal, cuidar do patrimônio documental é uma obrigação de todos. 


\section{Bibliografia}

Bellotto, Heloísa Liberalli. Arquivos permanentes: tratamento documental. 4.ed. Rio de Janeiro: Editora FGV, 2007.

Cambraia, César Nardelli. Introdução à crítica textual. São Paulo: Martins Fontes, 2005.

Funari, Pedro Paulo. Os historiadores e a cultura material. In: PINSKY, Carla Bassanezi (org.). Fontes históricas. São Paulo: Contexto, 2005.

Hamel, Christopher de. Manuscritos notáveis. Tradução Paulo Geiger. São Paulo: Companhia das Letras, 2017.

Lose, Alícia Duhá; Mazzoni, Vanilda Salignac de S. Uma história escrita à mão: Manuscritos do Antigo Recolhimento dos Humildes: documentos de uma história. Salvador: Memória\&Arte, 2016. v.2

Martins, Wilson. A palavra escrita: história do livro, da imprensa e da biblioteca. 3.ed. São Paulo: Ática, 2002.

Priore, Mary Del. Documentos históricos do Brasil. São Paulo: Panda Books, 2016. 